\title{
Response of deep soil moisture to land use and afforestation in the semi-arid Loess Plateau, China
}

\author{
Lei Yang ${ }^{a}$, Wei Wei ${ }^{a, *}$, Liding Chen ${ }^{a}$, Baoru Mo ${ }^{b}$ \\ a State Key Laboratory of Urban and Regional Ecology, Research Center for Eco-Environmental Sciences, Chinese Academy of Sciences, Beijing 100085, China \\ ${ }^{\mathrm{b}}$ Gansu Academy of Forestry Sciences, Lanzhou 730000, China
}

\section{A R T I C L E I N F O}

\section{Article history:}

Received 30 November 2011

Received in revised form 7 September 2012

Accepted 12 September 2012

Available online 4 October 2012

This manuscript was handled by Andras

Bardossy, Editor-in-Chief, with the

assistance of Vazken Andréassian, Associate Editor

\section{Keywords:}

Soil water

Vegetation restoration

Land use

Afforestation

Loess Plateau

\begin{abstract}
S U M M A R Y
Soil moisture is an effective water source for plant growth in the semi-arid Loess Plateau of China. Characterizing the response of deep soil moisture to land use and afforestation is important for the sustainability of vegetation restoration in this region. In this paper, the dynamics of soil moisture were quantified to evaluate the effect of land use on soil moisture at a depth of $2 \mathrm{~m}$. Specifically, the gravimetric soil moisture content was measured in the soil layer between 0 and $8 \mathrm{~m}$ for five land use types in the Longtan catchment of the western Loess Plateau. The land use types included traditional farmland, native grassland, and lands converted from traditional farmland (pasture grassland, shrubland and forestland). Results indicate that the deep soil moisture content decreased more than $35 \%$ after land use conversion, and a soil moisture deficit appeared in all types of land with introduced vegetation. The introduced vegetation decreased the soil moisture content to levels lower than the reference value representing no human impact in the entire $0-8 \mathrm{~m}$ soil profile. No significant differences appeared between different land use types and introduced vegetation covers, especially in deeper soil layers, regardless of which plant species were introduced. High planting density was found to be the main reason for the severe deficit of soil moisture. Landscape management activities such as tillage activities, micro-topography reconstruction, and fallowed farmland affected soil moisture in both shallow and deep soil layers. Tillage and micro-topography reconstruction can be used as effective countermeasures to reduce the soil moisture deficit due to their ability to increase soil moisture content. For sustainable vegetation restoration in a vulnerable semi-arid region, the plant density should be optimized with local soil moisture conditions and appropriate landscape management practices.
\end{abstract}

(c) 2012 Elsevier B.V. All rights reserved.

\section{Introduction}

Soil moisture is a critical component of the terrestrial system and plays an integrative role in surface processes (Legates et al., 2011). This is particularly true in semi-arid areas. In such regions, hydrologic viability (in terms of soil moisture availability) is considered to be the most important driver of the productivity and sustainability of terrestrial ecosystems (Jin et al., 2011; Mishra and Singh, 2010; Porporato et al., 2002). In the arid and semi-arid Loess Plateau of China, soil moisture is an important water source sustaining ecosystems (Chen et al., 2008a).

The Loess Plateau of China has a loess cover with an average thickness of $100 \mathrm{~m}$, and its erosion rate can reach 5000 $10,000 \mathrm{t} \mathrm{km}^{-2} \mathrm{a}^{-1}$ in several significant hilly regions (Chen et al., 2007b). The serious erosion condition is mainly a result of traditional agriculture, which involves cultivation on sloped land and low vegetation cover (Chen et al., 2007b; Wei et al., 2010). Vegeta-

\footnotetext{
* Corresponding author. Tel./fax: +86 1062849102.

E-mail address: weiwei@rcees.ac.cn (W. Wei).
}

tion restoration (by means of land use conversion) associated with afforestation that is designed to control serious soil erosion has been initiated by China's central government over the past three decades (Chen et al., 2010; Shi et al., 2009). Most of the traditional farmlands on steep slopes were converted to pasture grasslands, shrublands, and forestlands during this process (Liu et al., 2008a). Several types of introduced vegetation, including alfalfa (Medicago sativa Linn.), peashrub (Caranana korshinskii Kom.), sea buckthorn (Hippophae rhamnoides Linn.), and others, were used to cover the converted lands. The introduced vegetation has been shown to control soil erosion (Chen et al., 2007b) and aid in the reconstruction of dryland ecosystems (Liu et al., 2008a; Yang et al., 2010) in this region.

Generally, the introduced vegetation consists of nonnative plants that tend to consume more water (Sun et al., 2006; Cao et al., 2011; McVicar et al., 2010). Average annual rainfall in this area ranges from 300 to $650 \mathrm{~mm}$ (Chen et al., 2008a), while average annual pan evaporation can reach as high as $1669 \mathrm{~mm}$ (Xie and Wang, 2007). Obviously, the net result of low precipitation and high evaporation results in lower soil moisture content in the 
region (Yang and Tian, 2004), making the soil moisture insufficient for meeting the growth needs of the introduced vegetation. Groundwater levels in this region range from 30 to $100 \mathrm{~m}$ below surface (Mu et al., 2003), and groundwater at these depths is not a viable supply for soil evaporation and/or plant transpiration. For this reason, deep soil moisture stored in the unsaturated zone is critical for plant survival and becomes particularly important for the sustainable growth of introduced vegetation (Chen et al., 2008a).

Researchers have reported excessive consumption of soil water when afforestation with introduced vegetation is used in the vulnerable semi-arid Loess Plateau (Chen et al., 2008a; Yang et al., 2012). Local soils have become extremely dry in both deeper and shallow layers in the region, in turn diminishing the desired effect of afforestation in reducing soil erosion and improving local environment (Cao et al., 2011; Chen et al., 2008a; Wang et al., 2010b). Deep soil moisture is seldom recharged (Chen et al., 2008a), so restoration through the introduction of vegetation is limited by the available soil water resources. Negative impacts of the initially promoted afforestation have occurred because of deep soil desiccation, such as decreasing the restoration effort (Chen et al., 2010; Liu et al., 2010; Wang et al., 2011b), vegetation deterioration and difficulties in renewal and reforestation (Chen et al., 2008a), fluctuating agriculture crop production (Huang et al., 2003; Wang et al., 2008), and decreasing ecosystem services (Chazdon, 2008; Liu et al., 2008a). A decline in soil moisture has many other consequences for local water resources. For example, the groundwater recharge will be reduced in the long run and affect water yield at the regional scale (Scanlon et al., 2006; Gates et al., 2011; Sun et al., 2006). As global warming progresses, increased water stress in semi-arid regions is becoming an increasing concern (Arnell, 1999; Vörösmarty et al., 2000). A warming and drying trend on the Loess Plateau, in particular, will no doubt increase the surface water and soil moisture stress in the region (Liu et al., 2008b; Piao et al., 2010). For example, Pu et al. (2006) and Yao et al. (2005) found that a declining trend in soil moisture was associated with decreased precipitation and increased temperature based on 30 years of meteorological and soil moisture data.

With the large-scale land use conversion and afforestation over the past five decades, introduced vegetation has become the main vegetation type in the Loess Plateau. The broader impacts of largescale reforestation are a concern (Sun et al., 2006) because the vegetation water uses may affect the soil hydrologic balance. The soil moisture dynamics as a response to such large scale changes in land use may have significant implications for local ecosystem stability and sustainability. Several recent studies have been conducted on deep soil moisture depletion influenced by vegetation restoration and large-scale afforestation in the Loess Plateau. For instance, the soil moisture consumption rate was found to be dependent on vegetation type (Wang et al., 2010b, 2009b). Liu et al. (2010) found a negative relationship between deep soil moisture content and plant age. Yang et al. (2012) found a negative relationship between deep soil moisture content and plant growth conditions. Little work is available on soil moisture dynamics to different land use and afforestation approaches based on observations in deep layers associated with time series observations on shallow layers. In the meantime, different exotic vegetation types have been introduced for vegetation restoration in the Loess Plateau. Understanding the role of different types of cover in influencing deep soil moisture will provide a scientific basis for the optimization of vegetation restoration efforts, especially for semiarid regions. On the other hand, effective countermeasures to soil moisture deficits have been focused on shallow layer at a depth of 2 or $3 \mathrm{~m}$ in recent studies (Chen et al., 2008b), while our study focuses on the influence of landscape management on deep soil moisture dynamics.
In this study, we aim to reveal the response of deep soil moisture dynamic to different land use and afforestation approaches. Thus, we compare soil moisture content in different land uses to characterize the response of soil moisture to land use conversion using a "space replacing time" method. Because different nonnative plants were introduced in this large-scale vegetation restoration project, six typical types of introduced vegetation in the semi-arid Loess Plateau were selected to analyze the role of vegetation type on deep soil moisture dynamics. Furthermore, the influence of landscape management on deep soil moisture is discussed in this paper. The objectives of this study are to: (1) quantify the difference in soil moisture among different land use types; (2) compare soil moisture conditions among different (newly introduced) vegetation types; and (3) develop recommendations for the sustainability of the introduced vegetation as a long-term strategy for the Loess Plateau and other similar regions.

\section{Materials and methods}

\subsection{Study area}

The study site is located in the Longtan catchment $\left(35^{\circ} 43^{\prime}-\right.$ $35^{\circ} 46^{\prime} \mathrm{N}, 104^{\circ} 27^{\prime}-104^{\circ} 31^{\prime} \mathrm{E}$ ) in Dingxi, Gansu Province of China, covering an area of about $16.1 \mathrm{~km}^{2}$ with a highly fragmented landscape with an elevation ranging from 1840 to $2260 \mathrm{~m}$ above sea level. This typical semi-arid loess hilly region has a mean annual temperature of $6.8^{\circ} \mathrm{C}$ and a mean annual rainfall of $386 \mathrm{~mm}$. Most rainfall occurs in the form of thunderstorms during the summer months from July to September. The potential annual evaporation (pan evaporation) is about $1649 \mathrm{~mm}$. All meteorological data (1961-2006) were provided by a stand meteorological station located $0.6 \mathrm{~km}$ from the catchment. Since year 2007, five autorecording rain gauges were installed in the catchment to collect site-specific rainfall data. Soil types in this study area are mainly loess soil that have low fertility and is vulnerable to soil erosion. The soils have a loose structure, low soil water field capacity (18-24\%), and low organic matter content (ca. 0.2-2.9\%). The wilting point is about 5.4\% (Chen et al., 2007a). Soil thickness varies from $40 \mathrm{~m}$ to $60 \mathrm{~m}$.

The predominant land use types in the catchment are rain-fed farmland, sparse native grassland, pasture grassland, shrubland, forestland, and fallow cropland. The natural vegetation in the study area consists of sparse grass with annual plants and shallow roots dominated by species such as bunge needlegrass (Stipa bungeana Trin.), common leymus (Leymus secalinus (Georgi) Tzvel.), and Altai heterpappus (Heteropappus altaicus (Willd.) Novopokr.) The introduced vegetation types are alfalfa ( $M$. sativa), peashrub (C. korshinskii), Siberian apricot (Armeniaca sibirica (L.) Lam.), Chinese red pine (Pinus tabulaeformis Carr.), and others. As in semi-arid climatic zone, water is the major constraint to vegetation growth and agriculture crop production.

\subsection{Study site description}

In this study, three land uses were selected, including (1) traditional farmland, (2) native grassland and (3) land converted from traditional farmland. Furthermore, six specific vegetation covers were included: (1) alfalfa ( $M$. sativa), (2) peaches (A. davidiana), (3) peashrub (C. korshinskii), (4) Chinese arborvitae (Platycladus orientalis), (5) Chinese red pine ( $P$. tabulaeformis), and (6) Siberian apricot (A. sibirica). Afforestation was associated with the vegetation restoration (land use conversion) process. The peaches, peashrub, Chinese arborvitae, Chinese red pine, and Siberian apricot were planted on traditional farmland. 


\subsubsection{Traditional farmland}

The traditional farmland was planted with annual crops in a millet-potato-flax rotation system, typically on sloped fields. Crops were sown in April and harvested manually at the end of September or beginning of October. A fallow period was followed from October to March of the next year. In 2007 and 2010, potatoes were planted on this traditional farmland.

\subsubsection{Native grassland}

This is the dominant community of native species in the study region. The main species are native grasses and herbs, including with low water demands: common leymus (L. secalinus), bunge needlegrass (S. bungeana), Altai heterpappus (H. altaicus), capillary wormwood (Artemisia capillaris Thunb.), Mongolian thyme (Thymus mongolicus Ronn.), and others. According to local farmers and stakeholders, the natural grasslands were kept from human disturbance for at least 50 years.

\subsubsection{Land converted from traditional farmland}

These areas were covered with the introduced vegetation when the conversion took place. The converted lands generally include pasture, shrub, and forest. In this study, pasture alfalfa was planted in 2003 on sloped fields after initiation of Grain to Green program (GTGP, also known as the Sloping Land Conversion Program and the Farm to Forest Program, Liu et al., 2008a). In rainfall-deficit years, alfalfa was cut only once because of its poor growth; otherwise, it was cut twice annually. David peach and peashrub were planted on traditional farmland in 1980 and 1984, respectively.
Chinese arborvitae, Chinese red pine, and Siberian apricot were planted in 1980,1972, and 1960, respectively.

To study the effect of landscape management and introduced vegetation on soil moisture, lands with micro-topographic reconstruction were selected for comparison with traditional agriculture (farming on sloped fields) and traditional afforestation (afforestation on sloped fields). The terrace farmland, or land with micro-topographic reconstruction, was converted from a method of traditional agriculture on sloped lands. The cultivation and management system for terrace farmlands was the same as that used for traditional farmlands. In order to control soil erosion, fallow was used in the landscape management practices since 2002. Chinese red pine was planted on the micro-terrace in 1972 and the micro-terrace was selected in this study to compare the soil moisture content with traditional afforestation.

In the study area, each plot was covered a single type of vegetation from top to bottom. To represent regional topographic properties and compare soil moisture conditions among different types of vegetation, all of the sampling sites were located in the center of each plot with similar slope gradients and positions. The distance of each sampling site was at least $100 \mathrm{~m}$. Soil properties in the deep layers of the ground are homogeneous in the Loess Plateau. The soil moisture content and profile distribution were calculated by taking the mean value of all sampling sites with the same land use/vegetation cover in each soil layer. The number of sampling sites for each land use/vegetation type is shown in Table 1.

The soil moisture profile in the traditional farmland was used as the reference to present the conditions prior to land use

Table 1

General information for the experimental sites.

\begin{tabular}{|c|c|c|c|c|c|c|c|c|c|c|c|c|c|}
\hline Land use & $\begin{array}{l}\text { Land cover } \\
\text { subclasses }\end{array}$ & Vegetation & Year & $\begin{array}{l}\text { Number } \\
\text { of sites }\end{array}$ & $\begin{array}{l}\text { Mean } \\
\text { canopy } \\
\text { coverage } \\
(\%)\end{array}$ & $\begin{array}{l}\text { Mean } \\
\text { canopy } \\
\text { height } \\
(\mathrm{m})\end{array}$ & $\begin{array}{l}\text { Mean } \\
\text { tree } \\
\text { DBH } \\
(\mathrm{cm})\end{array}$ & $\begin{array}{l}\text { Planting } \\
\text { density }\end{array}$ & $\begin{array}{l}\text { Bulk } \\
\text { density } \\
\left(\mathrm{g} / \mathrm{cm}^{3}\right)\end{array}$ & $\begin{array}{l}\text { Porosity } \\
(\%)\end{array}$ & $\begin{array}{l}\text { Clay } \\
(\%)\end{array}$ & $\begin{array}{l}\text { Silt } \\
(\%)\end{array}$ & $\begin{array}{l}\text { Sand } \\
(\%)\end{array}$ \\
\hline $\begin{array}{l}\text { Traditional } \\
\text { agriculture }\end{array}$ & $\begin{array}{l}\text { Traditional } \\
\text { farmland }\end{array}$ & $\begin{array}{l}\text { Potato } \\
\text { (Solanum } \\
\text { Tuberosum) }\end{array}$ & - & 2 & 42 & 0.5 & - & $0.3 \times 0.3 \mathrm{~m}$ & 1.05 & 49.53 & 6.14 & 79.17 & 14.69 \\
\hline Native grassland & $\begin{array}{l}\text { Native } \\
\text { grassland }\end{array}$ & $\begin{array}{l}\text { Native grasses } \\
\text { and herbs }\end{array}$ & $>50$ & 4 & 74 & 0.1 & - & - & 1.08 & 53.53 & 5.12 & 82.58 & 12.30 \\
\hline \multirow{6}{*}{$\begin{array}{l}\text { Land converted } \\
\text { from } \\
\text { traditional } \\
\text { farmland }\end{array}$} & $\begin{array}{l}\text { Pasture } \\
\text { grassland }\end{array}$ & $\begin{array}{l}\text { Alfalfa } \\
\text { (Medicago } \\
\text { sativ.) }\end{array}$ & 7 & 6 & 98 & 0.6 & - & - & 1.15 & 45.27 & 5.30 & 81.70 & 13.00 \\
\hline & Shrubland & $\begin{array}{l}\text { David peach } \\
\text { (Amygdalus } \\
\text { davidiana) }\end{array}$ & 30 & 3 & 75 & 2.0 & - & $1.0 \times 4.5 \mathrm{~m}$ & 1.06 & 57.16 & 6.49 & 83.20 & 10.31 \\
\hline & & $\begin{array}{l}\text { Peashurb } \\
\text { (Caranana } \\
\text { korshinskii) }\end{array}$ & 26 & 5 & 45 & 1.1 & - & $1.0 \times 4.5 \mathrm{~m}$ & 1.20 & 49.76 & 6.18 & 78.37 & 15.45 \\
\hline & Forestland & $\begin{array}{l}\text { Chinese } \\
\text { arborvitae } \\
\text { (Platycladus } \\
\text { orientalis) }\end{array}$ & 30 & 4 & 70 & 4.2 & 3.6 & $1.5 \times 3.5 \mathrm{~m}$ & 1.10 & 52.64 & 5.44 & 81.53 & 13.03 \\
\hline & & $\begin{array}{l}\text { Chinese red } \\
\text { pine (Pinus } \\
\text { tabulaeformis) }\end{array}$ & 38 & 4 & 85 & 4.7 & 7.4 & $1.5 \times 3.5 \mathrm{~m}$ & 1.05 & 53.21 & 6.20 & 78.41 & 15.39 \\
\hline & & $\begin{array}{l}\text { Siberian apricot } \\
\text { (Armeniaca } \\
\text { sibirica) }\end{array}$ & 40 & 3 & 82 & 3.3 & 6.4 & $1.5 \times 3.5 \mathrm{~m}$ & 1.16 & 48.94 & 5.28 & 81.68 & 13.04 \\
\hline \multirow{3}{*}{$\begin{array}{l}\text { Land with } \\
\text { landscape } \\
\text { management } \\
\text { measures }\end{array}$} & $\begin{array}{l}\text { Terrace } \\
\text { farmland }\end{array}$ & $\begin{array}{l}\text { Potato } \\
\text { (Solanum } \\
\text { Tuberosum) }\end{array}$ & - & 5 & 42 & 0.5 & - & $0.3 \times 0.3 \mathrm{~m}$ & 1.10 & 49.61 & 5.97 & 82.30 & 11.73 \\
\hline & $\begin{array}{l}\text { Fallow } \\
\text { farmland }\end{array}$ & $\begin{array}{l}\text { Native grasses } \\
\text { and herbs }\end{array}$ & 8 & 4 & 65 & 0.3 & - & - & 1.05 & 53.78 & 6.05 & 84.22 & 9.73 \\
\hline & $\begin{array}{l}\text { Terrace } \\
\text { Chinese red } \\
\text { pine }\end{array}$ & $\begin{array}{l}\text { Chinese red } \\
\text { pine (Pinus } \\
\text { tabulaeformis) }\end{array}$ & 38 & 2 & 88 & 4.8 & 7.6 & $1.5 \times 3.5 \mathrm{~m}$ & 1.08 & 52.98 & 7.08 & 74.33 & 18.58 \\
\hline
\end{tabular}

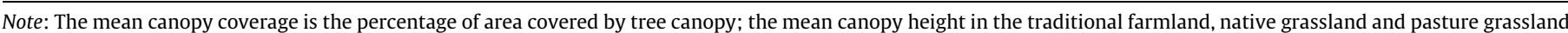

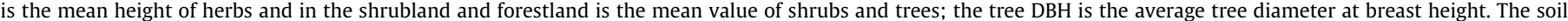
properties are mean values of all experimental sites for each land use/vegetation. 
conversion. The difference in soil moisture between traditional farmland and the converted lands reflect the response of soil moisture to the change in land use. The soil moisture content in native grassland could be considered as the reference value representing no human impact in the study area. Similarly, the difference in soil moisture between native grassland and lands with introduced vegetation indicate the degree of the soil moisture deficit relative to the initial soil moisture condition (Fig. 1).

\subsection{Data collection and analysis}

Soil moisture measurements in the growing season were made biweekly (beginning and middle of each month) for the $2 \mathrm{~m}$ profile in 20-cm increments, from April to October in 2009 and 2010. Soil samples were taken by a drill stored in sealed aluminum cases, and were analyzed for soil moisture content in the laboratory using gravimetric approach (Dobriyal et al., 2012). The soil moisture content was determined using the oven-dry method $\left(24 \mathrm{~h}\right.$ at $\left.105^{\circ} \mathrm{C}\right)$. In 2010 , the gravimetric soil moisture content in the 2-8 m layers was measured at each field sampling site. Each time the soils were sampled, three sampling profiles were randomly chosen to calculate the average soil moisture value for each sampling site.

At each sampling site, undisturbed soil cores were collected in metal cylinders (diameter $5 \mathrm{~cm}$, length $5 \mathrm{~cm}$ ) for the soil bulk density measurement. Bulk density and porosity were determined from the volume-mass relationship for each core sample. Soil samples were also collected at each sampling site. Soil particle sizes were evaluated using the MasterSizer 2000 apparatus manufactured by Malvern. The proportion of clay $(<0.002 \mathrm{~mm})$, silt $(0.002-0.02 \mathrm{~mm})$, and sand $(>0.02 \mathrm{~mm})$ content were then calculated. At each sampling site, a vegetation investigation was also conducted. In forest sites, the stand density (plants/ha), tree height $(\mathrm{m})$, diameter at the breast height (DHB, cm), canopy width in a $20 \mathrm{~m} \times 20 \mathrm{~m}$ quadrat, and total canopy or coverage of each quadrat were recorded. In shrub sites, plant height $(\mathrm{m})$ and canopy width in a $20 \mathrm{~m} \times 20 \mathrm{~m}$ quadrat were measured. The canopy cover was measured by visual estimation. Species composition, total

(a)
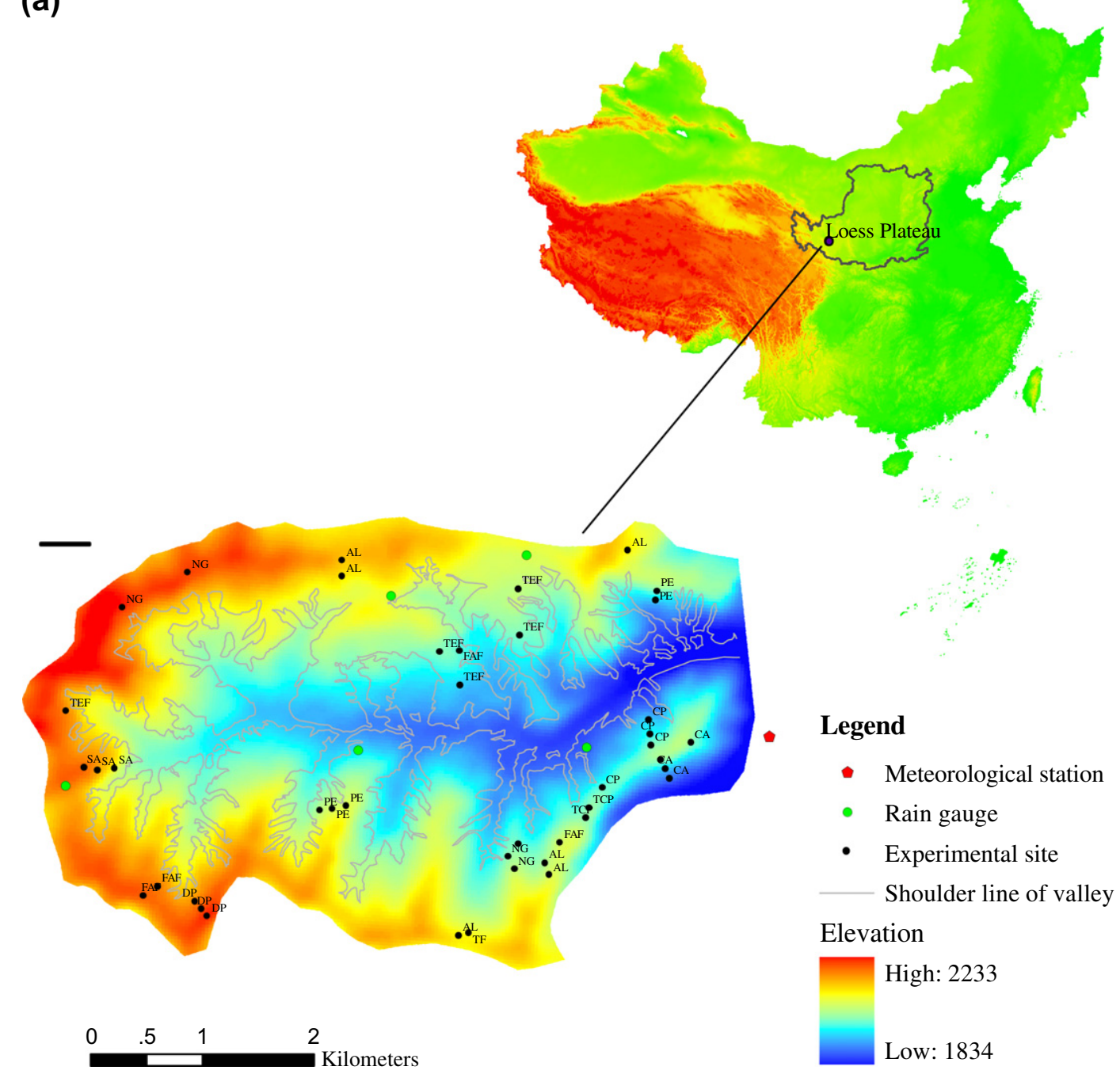

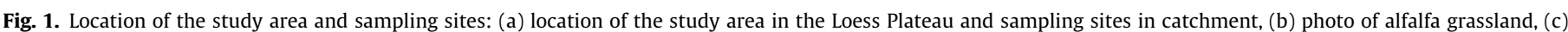

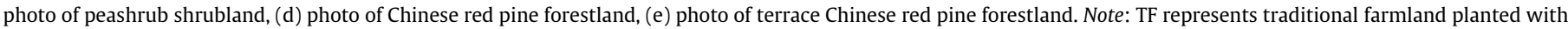

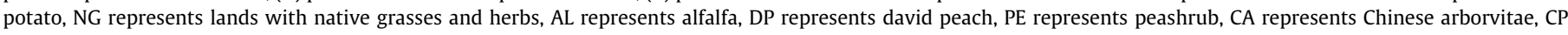

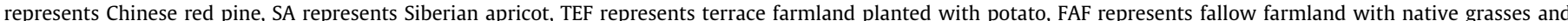

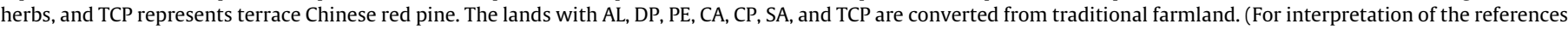
to color in this figure legend, the reader is referred to the web version of this article.) 
(b)

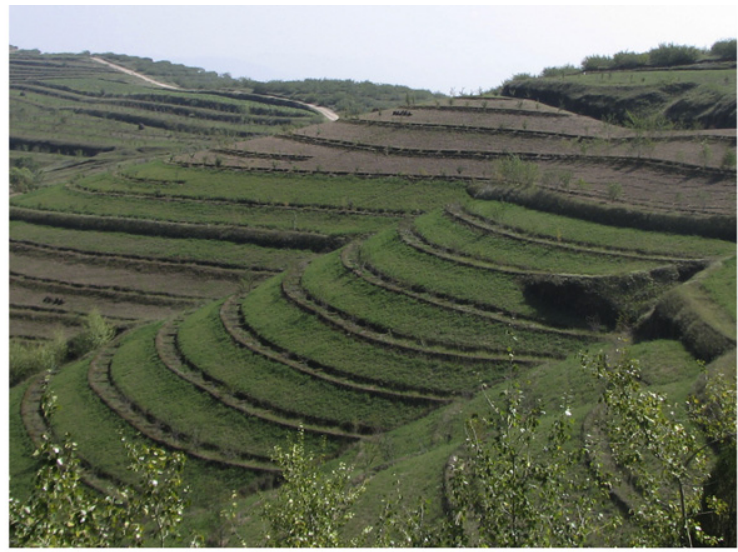

(d)

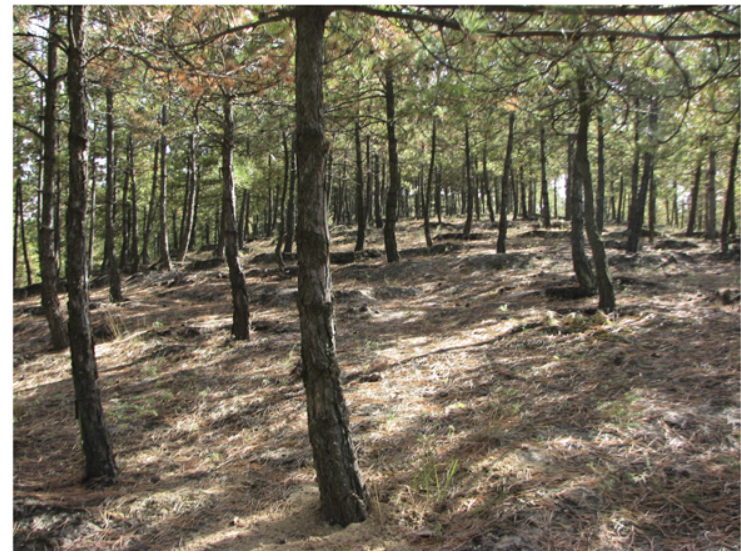

(c)

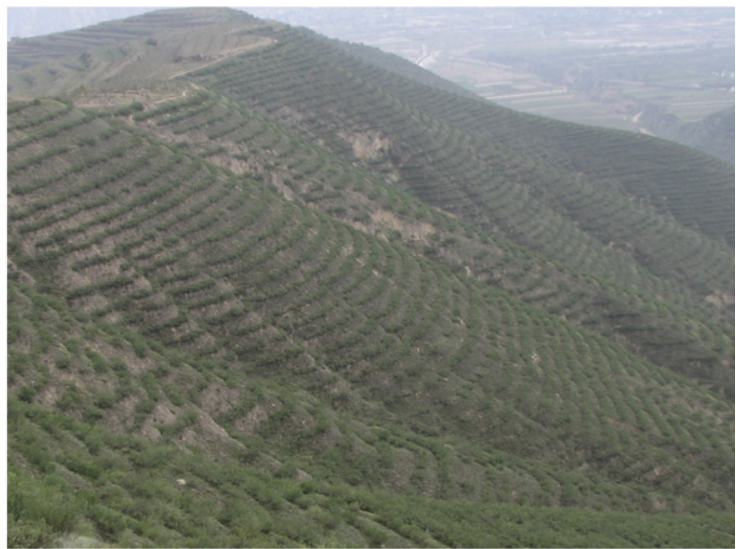

(e)

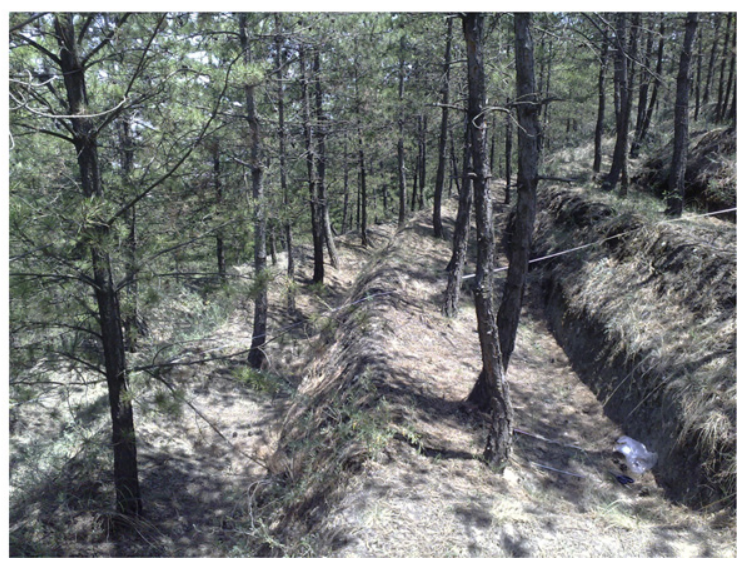

Fig. 1. (continued)

herbaceous coverage, plant height, and biomass were measured in each herbaceous quadrat (Table 1).

\subsection{Statistical methods}

The depth-averaged soil moisture content for each site at each measurement time $\left(\theta_{i j}\right)$ was calculated by the following equation:

$\theta_{i j}=\frac{1}{i} \sum_{i=1}^{i} \theta_{i}$

where $i$ is the number of measurement layers at site $j$, and $\theta_{i}$ is the mean soil moisture content in layer $i$ calculated by three random sampling profiles. In this study, the soil moisture content was calculated for the $0-1 \mathrm{~m}, 1-2 \mathrm{~m}$, and 2-8 m layers, respectively.
The depth-averaged soil moisture content $\left(\theta_{m}\right)$ for each land use/vegetation type at each measurement time was calculated by the following equation:

$\theta_{m}=\frac{1}{k} \sum_{k=1}^{k} \theta_{i j}$

where $k$ was the number of experimental sites for each land use/ vegetation type (Table 1 ).

The temporal- and depth-averaged soil moisture content of each land use/vegetation type was calculated by the following equation:

$\bar{\theta}_{m}=\frac{1}{n} \sum_{n=1}^{n} \theta_{m}$

Table 2

Soil moisture content in the 0-8 m layers among the different land use types.

\begin{tabular}{|c|c|c|c|c|c|c|c|c|c|c|c|c|}
\hline \multirow[t]{2}{*}{ Land use subclasses } & \multicolumn{4}{|l|}{$0-1 \mathrm{~m}$} & \multicolumn{4}{|l|}{$1-2 \mathrm{~m}$} & \multicolumn{4}{|l|}{$2-8 \mathrm{~m}$} \\
\hline & $\operatorname{Min}(\%)$ & $\operatorname{Max}(\%)$ & Mean (\%) & SD & $\operatorname{Min}(\%)$ & $\operatorname{Max}(\%)$ & Mean (\%) & SD & $\operatorname{Min}(\%)$ & $\operatorname{Max}(\%)$ & Mean (\%) & SD \\
\hline Traditional farmland & 5.6 & 11.4 & 8.3 & $1.49_{(\mathrm{n}=25)}$ & 5.7 & 11.8 & 7.7 & $1.26_{(\mathrm{n}=25)}$ & 8.3 & 14.1 & $11.6^{\mathrm{a}^{*}}$ & $1.74_{(\mathrm{n}=30)}$ \\
\hline Native grassland & 5.4 & 9.7 & 7.3 & $1.21_{(\mathrm{n}=25)}$ & 5.4 & 9.6 & 6.8 & $0.80_{(\mathrm{n}=25)}$ & 6.8 & 13.0 & $10.3^{\mathrm{b}}$ & $1.89_{(\mathrm{n}=30)}$ \\
\hline Pasture grassland & 6.1 & 11.5 & 8.4 & $1.43_{(\mathrm{n}=25)}$ & 5.6 & 7.6 & 6.4 & $0.45_{(\mathrm{n}=25)}$ & 6.0 & 9.2 & $7.5^{\mathrm{c}}$ & $1.03_{(\mathrm{n}=30)}$ \\
\hline Shrubland & 4.4 & 9.7 & 6.5 & $1.22_{(\mathrm{n}=50)}$ & 5.0 & 7.9 & 6.0 & $0.75_{(\mathrm{n}=50)}$ & 5.8 & 9.1 & $7.4^{\mathrm{c}}$ & $0.98_{(\mathrm{n}=30)}$ \\
\hline Forestland & 4.3 & 13.4 & 7.0 & $1.84_{(\mathrm{n}=75)}$ & 4.2 & 7.7 & 5.7 & $0.49_{(\mathrm{n}=75)}$ & 5.7 & 8.3 & $7.2^{c}$ & $0.90_{(\mathrm{n}=30)}$ \\
\hline$p$ Value & & & $0.000^{* *}$ & & & & $0.000^{* *}$ & & & & $0.000^{* *}$ & \\
\hline
\end{tabular}

* Means with the same letter in the same column are not significantly different at the 0.05 level (LSD test, 0.05).

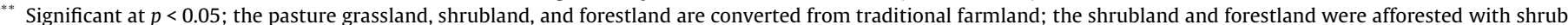
(david peach and peashrub) and arbor (Chinese arborvitae, Chinese red pine and Siberian apricot) plants. 
where $n$ is the number of measurement times during growing seasons $(n=25)$.

Basic population statistics, such as minimum values (Min), maximum values (Max), mean values (Mean), and standard deviations (SDs) were reported for each land use and vegetation cover type. One-way ANOVA was used to assess the contribution of different land use and vegetation cover types to the overall variation in the soil moisture variables. Multiple comparisons were made using the least significant difference (LSD) method. SPSS ${ }^{\circledR}$ (Version 18.0) was used for all statistical analyses.

\section{Results}

\subsection{Soil moisture profile in different land use types}

The soil moisture content at comparable soil depths was lower in pasture grassland, shrubland, and forestland as compared with traditional farmland and native grassland, especially in the depth below $1 \mathrm{~m}$ (Table 2, Fig. 2). The soil moisture content in native grassland (6.8\% in $1-2 \mathrm{~m}$ and $10.3 \%$ in $2-8 \mathrm{~m}$ ) was lower than that in traditional farmland (7.7\% in $1-2 \mathrm{~m}$ and $11.6 \%$ in $2-8 \mathrm{~m}$ ), but
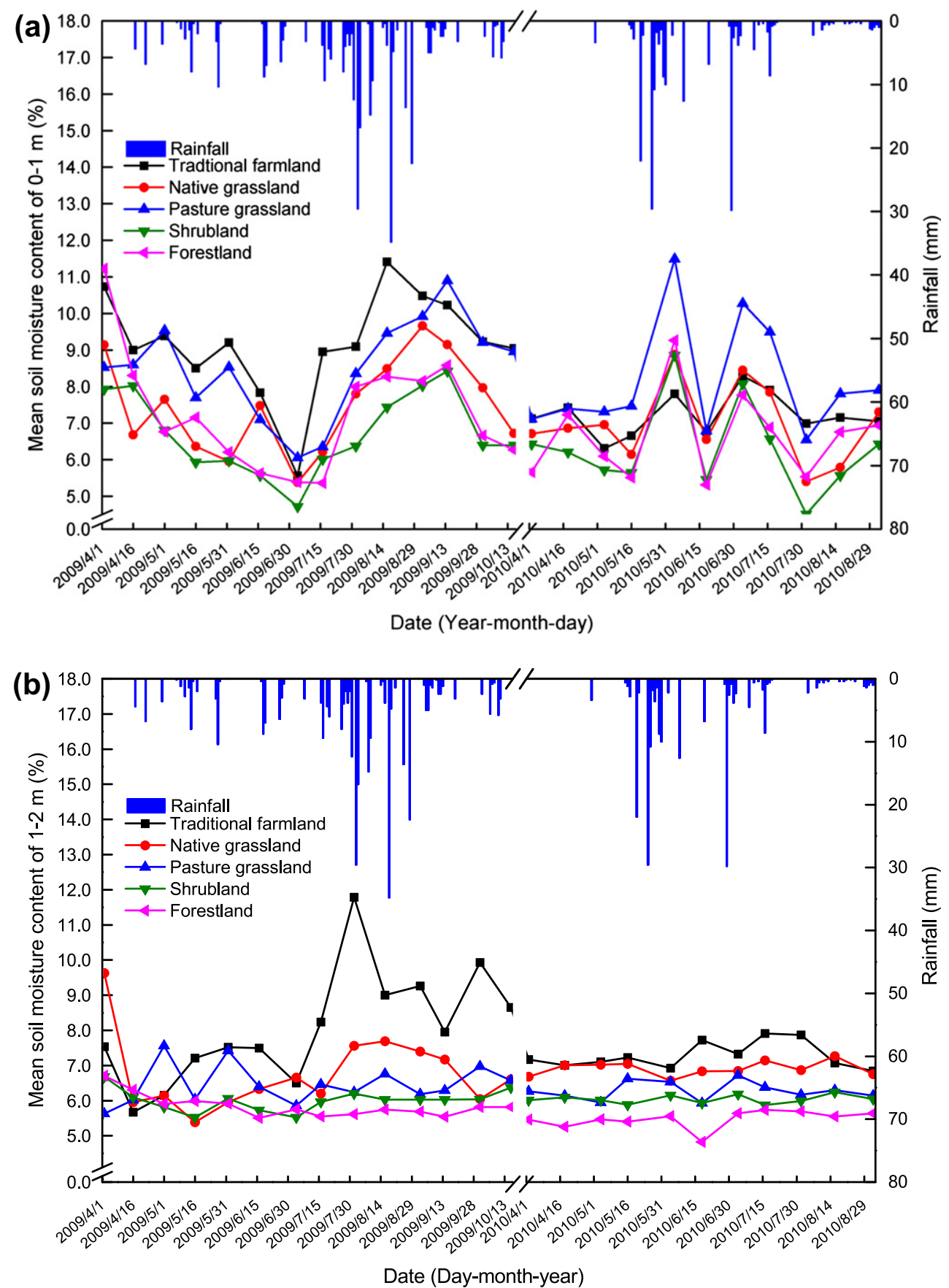

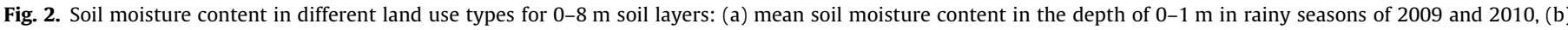

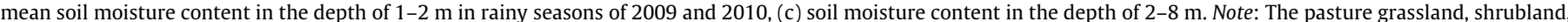

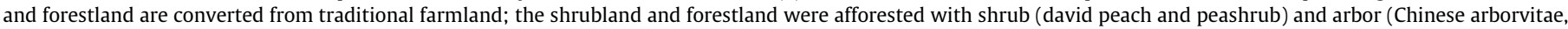
Chinese red pine and Siberian apricot) plants. 
(c)

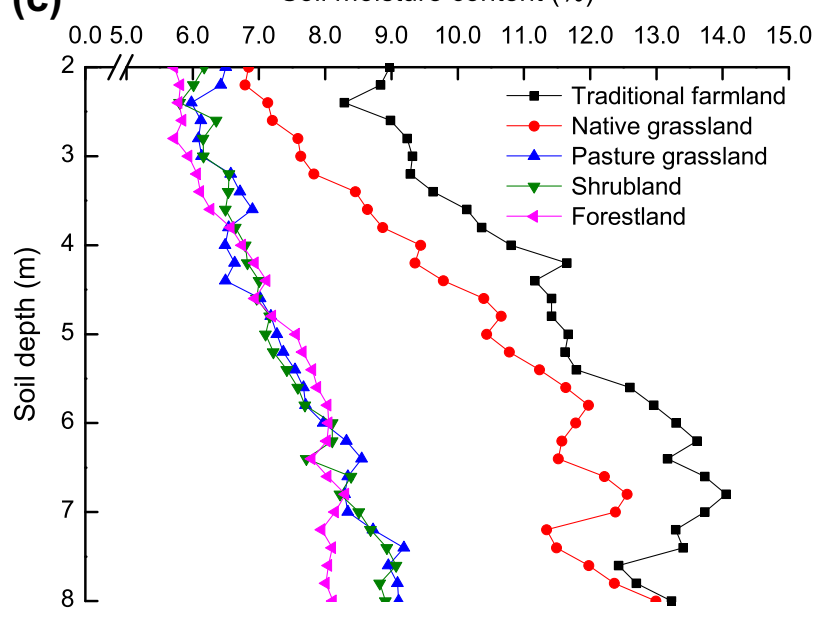

Fig. 2. (continued)

higher than that in the converted lands (5.7-6.4\% in 1-2 $\mathrm{m}$ and $7.2-7.5 \%$ in $2-8 \mathrm{~m}$ ). The soil moisture content in the $0-1 \mathrm{~m}$ layer was higher than that in the 1-2 m layer (Table 2); however, the value in this depth varied drastically with rainfall (Fig. 2a). With the exception of traditional farmland, the soil moisture content in the 1-2 m layer did not appear to be affected much by the rainfall fluctuation (Fig. 2b). Higher soil moisture content was observed in the traditional farmland $(8.3 \%$ in $0-1 \mathrm{~m}, 7.7 \%$ in $1-2 \mathrm{~m}$ and $11.6 \%$ in $2-$ $8 \mathrm{~m}$ ) as compared with other land use types. Interestingly, the soil moisture content of pasture grassland varied from $6.1 \%$ to $11.5 \%$ in the $0-1 \mathrm{~m}$ layer, with an average value of $8.4 \%$, which was higher than that for other land use types. However, the soil moisture content in pasture grassland was lower than that of traditional farmland and native grassland below the depth of $1 \mathrm{~m}$.

The statistical analysis showed no significant differences among the land use types converted from traditional farmland in the deep soil layers. This indicates that the three converted land use types may have similar effects on soil moisture in deep layers. Generally, traditional farmland had the highest soil moisture content and forestland had the lowest value for the overall 0-8 m layer. The value of the soil moisture content increased with increasing soil depth in the deep layers for the five different land use types (Fig. 2c).

\subsection{Soil moisture in different vegetation covers}

The soil moisture content in land with different types of vegetation cover changed drastically with rainfall fluctuations in the shallow depth of $0-1 \mathrm{~m}$ (Fig. 3a). However, the fluctuation of rainfall in the rainy season had very little influence on soil moisture at the depth of 1-2 $\mathrm{m}$ with the exception of traditional farmland (Fig. 3b). Soil moisture content at depths below $1 \mathrm{~m}$ was lower in lands with exotic species (5.4-6.7\% in $1-2 \mathrm{~m}$ and $6.9-7.8 \%$ in $2-$ $8 \mathrm{~m}$ ) than that in lands with traditional agriculture $(7.7 \%$ in $1-$ $2 \mathrm{~m}$ and $11.6 \%$ in $2-8 \mathrm{~m}$ ) and native grass $(6.8 \%$ in $1-2 \mathrm{~m}$ and $10.3 \%$ in $2-8 \mathrm{~m}$ ). This was especially true in the deeper soil layers.

Planting density of the two types of shrubland (david peach and peashrub) was near 2222 plants/ha, and planting density of the three types of forestland (Chinese arborvitae, Chinese red pine and Siberian apricot) was near 1900 plants/ha. Interestingly, based on the comparison of mean soil moisture content and the LSD test, no significant difference was found between the introduced vegetation lands except for the david peach shrubland at the depth below $2 \mathrm{~m}$ (Table 3 ). The similar deep soil moisture response to different introduced vegetation types (i.e., alfalfa, peashrub,
Chinese arborvitae, Chinese red pine and Siberian apricot) suggests similar effects on the dynamic patterns of deep soil moisture in the study area. The vertical distribution of deep soil moisture content in lands with different types of vegetation cover is displayed in Fig. 3c.

\subsection{Effects of landscape management on soil moisture dynamics}

The soil moisture data used to compare soil moisture dynamics between different landscape management practices were obtained in August 2010. Because the data were collected during the rainy season, soil moisture content in the topsoil layer was relatively higher than the temporal-averaged soil moisture in other types of vegetation. The soil moisture content in terrace farmland was higher than that in traditional farmland, particularly in the 0-2 m soil layer (Fig. 4a). However, no statistically significant difference was found in the layers below $2 \mathrm{~m}$ (Table 4 ) for the two management systems. Compared with traditional farmland, the soil moisture content in fallow farmland decreased in all soil layers between 0 and $8 \mathrm{~m}$. The soil moisture in fallow farmland was near the value of native grassland, and no significant difference was found between the two types of vegetation cover in deep layers.

The difference between traditional farmland, terrace farmland and fallow farmland appeared to become smaller with increasing soil depth. The difference between traditional farmland and terrace farmland showed that micro-topography reconstruction can effectively increase soil moisture content. Furthermore, this effect was observed to be greater in the shallower soil layers than deeper layers. No obvious difference appeared between Chinese red pine and Terrace Chinese red pine in the layers between 2 and $4.2 \mathrm{~m}$ (Fig. 4b). However, the soil moisture content in Terrace Chinese red pine was higher than that planted on sloped land in the 0$1 \mathrm{~m}$ and 2-8 $\mathrm{m}$ layers. This result indicates that micro-topography affects soil moisture in shallow layers as well as deep soil layers.

\section{Discussion}

\subsection{Soil moisture profile characteristics in the Loess Plateau}

The soil moisture in the upper soil layers was more influenced by vegetation transpiration and soil evaporation as shown in studies by Meerveld and McDonnell (2006) and Seneviratne et al. (2010). In the upper layers, vegetation transpiration and soil evaporation combined could consume as much as $60 \%$ of total precipitation (Oki and Kanae, 2006), though Wang et al. (2011a) found that transpiration and evaporation could consume $90 \%$ of total precipitation in the Loess Plateau. For this reason, low soil moisture content is expected in shallow layers, especially in arid and semi-arid areas (Mishra and Singh, 2010). Yang and Tian (2004) pointed out that loess has a strong capacity for evaporation, which could result in continuously low soil moisture content.

Based on the long-term observation of climate data, the mean annual potential evaporation $(1649 \mathrm{~mm})$ was nearly 4.3 times more than mean annual rainfall $(386 \mathrm{~mm})$. This can explain the overall low soil moisture content in the shallow layers (Table 2, Table 3). Since soil moisture in topsoil could be compensated by annual precipitation, the mean soil moisture content in the $0-1 \mathrm{~m}$ layer was relatively higher than that in the 1-2 m layer (Table 2 , Table 3 ). On the other hand, the soil moisture in depth of 1-2 m was less affected by rainfall in lands with introduced vegetation (Figs. 2b and $3 \mathrm{~b}$ ). Soil moisture content in the 1-2 $\mathrm{m}$ soil layer could be substantially affected by plant root systems (Cong et al., 1990; February and Higgins, 2010), resulting in drier zones compared to the upper or deeper soil layers. As shown in Tables 2 and 3 , the mean moisture at the 1-2 m depth was near the wilting 

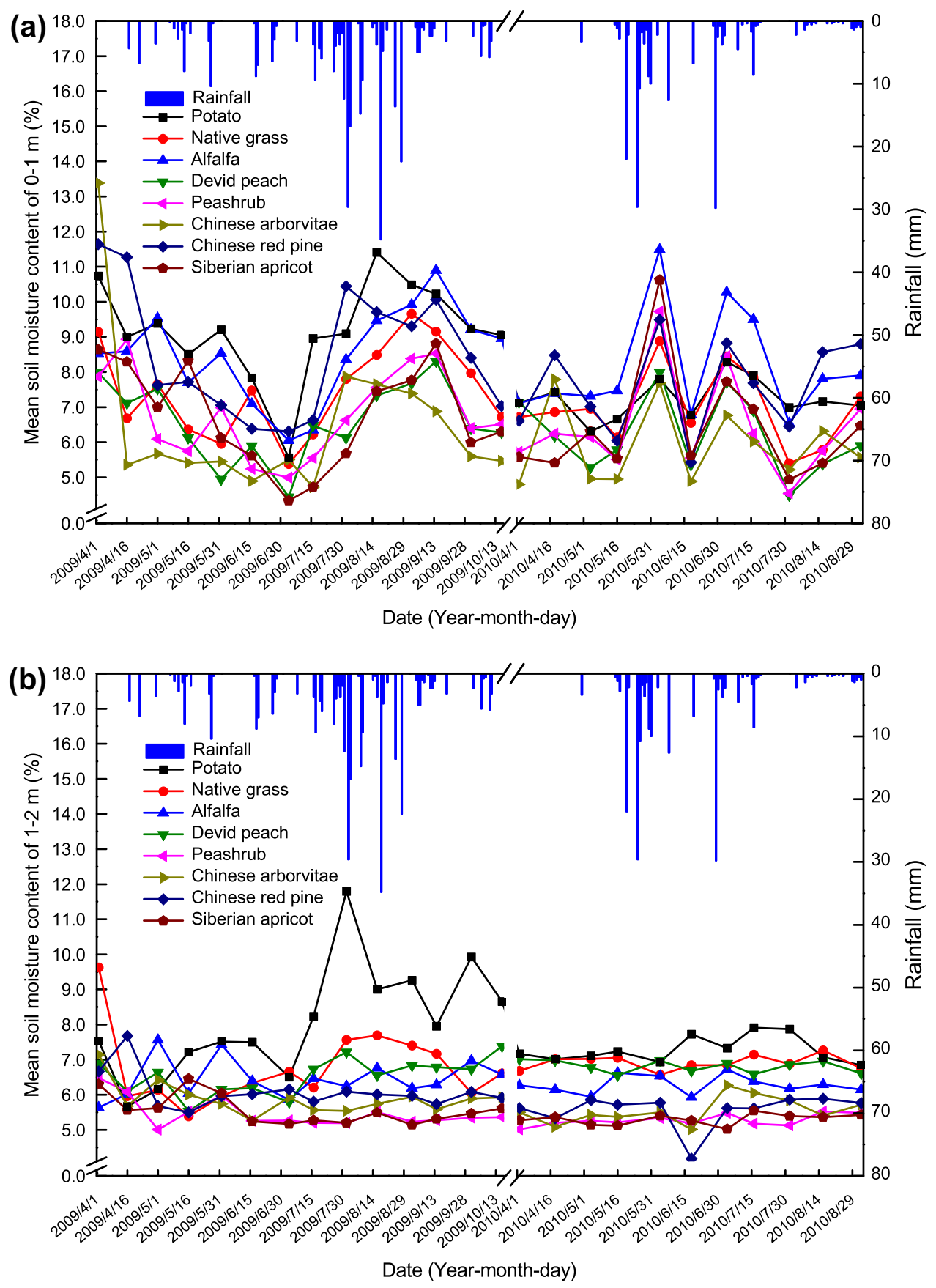

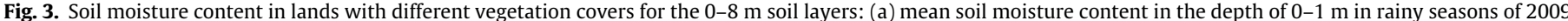

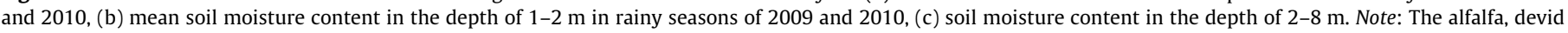
peach, peashrub, Chinese arborvitae, Chinese red pine, and Siberian apricot belong to introduced vegetation.

point (Chen et al., 2007a) in the study area. Beyond the root zone (i.e. below $2 \mathrm{~m}$ ), the soil moisture increased steadily with soil depth. The results of this study also indicate that rainfall minimally influences soil moisture at depths greater than $1 \mathrm{~m}$.

In the semi-arid Loess Plateau, soil moisture content varies in the depth of $0-2 \mathrm{~m}$ between years, depending on the annual precipitation. However, due to the thickness of the loess cover in the Loess Plateau, the soil profile distribution and temporal variation of soil moisture content are unique (Jin et al., 2011; Yang and Tian, 2004). Wang et al. (2009b) found that no significant difference in soil moisture occurred below $2 \mathrm{~m}$ between years based on longterm observations ( 6 years) in the loess hilly region. Chen et al. (2008b) found that the depth of soil affected by the rainfall was
$0-2 \mathrm{~m}$ in the drought year using monitoring data and simulations. Furthermore, the annual rainfall recharge was barely reached $1 \mathrm{~m}$ in the study area based on the field soil moisture observations (Yang et al., 2011). In the current study, the recharge depth was in the $0-1 \mathrm{~m}$ soil depths. No obvious differences appeared in the 1-2 $\mathrm{m}$ soil layers with the exception of traditional farmland (Figs. 2 and 3). The annual rainfall measures in 2009 and 2010 were 315 and $282 \mathrm{~mm}$, respectively. The relatively lower rainfall in 2009 and 2010 resulted in less soil moisture replenishment. In our opinion, the deep soil moisture content data observed in 1 year can be used to reflect the stable soil moisture conditions in the deep soil profiles, though further study is required to substantiate this statement. 
Soil moisture content (\%)

$\begin{array}{llllllllllll}0.0 & 5.0 & 6.0 & 7.0 & 8.0 & 9.0 & 10.0 & 11.0 & 12.0 & 13.0 & 14.0 & 15.0\end{array}$

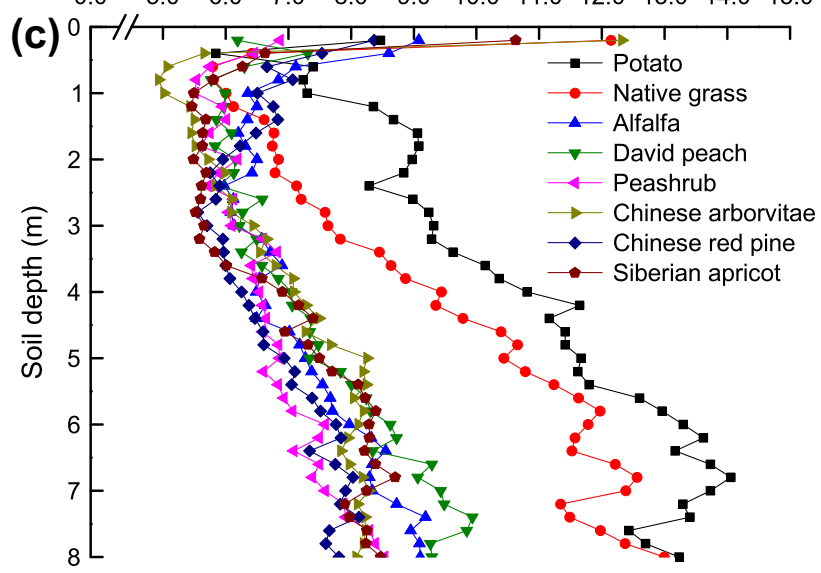

Fig. 3. (continued)

\subsection{Soil moisture deficit due to the vegetation restoration}

The difference in soil moisture content between traditional farmland and converted land was used to compare differences resulting from different land use. The results demonstrated that the soil moisture in all types of converted land was lower than that in the traditional farmland for all soil layers. The difference increased with increasing soil depth (Fig. 2c). As compared with traditional farmland, the deep soil moisture (below $2 \mathrm{~m}$ ) in pasture grassland decreased $35.6 \%$, while that in shrubland and forestland decreased $36.1 \%$ and $37.7 \%$, respectively. For the sloped farmland covered with introduced vegetation, a drastic soil moisture decrease was observed both in the shallow and deep soil layers regardless of the converted land use types. It should be noted that the soil moisture approached the wilting point (Chen et al., 2007a) in pasture grassland, shrubland, and forestland in some soil layers. This decreasing trend in soil moisture may lead to the deep layer soil moisture being unavailable for sustainable growth of introduced vegetation.

Table 3

Soil moisture of $0-8 \mathrm{~m}$ soil layers with different types of vegetation cover.

\begin{tabular}{|c|c|c|c|c|c|c|c|c|c|c|c|c|c|}
\hline \multirow{2}{*}{$\begin{array}{l}\text { Land use } \\
\text { subclasses }\end{array}$} & \multirow[t]{2}{*}{ Vegetation types } & \multicolumn{4}{|c|}{$0-1 \mathrm{~m}$} & \multicolumn{4}{|c|}{$1-2 \mathrm{~m}$} & \multicolumn{4}{|c|}{$2-8 \mathrm{~m}$} \\
\hline & & $\begin{array}{l}\text { Min } \\
(\%)\end{array}$ & $\begin{array}{l}\text { Max } \\
(\%)\end{array}$ & $\begin{array}{l}\text { Mean } \\
(\%)\end{array}$ & SD & $\begin{array}{l}\text { Min } \\
(\%)\end{array}$ & $\begin{array}{l}\text { Max } \\
(\%)\end{array}$ & $\begin{array}{l}\text { Mean } \\
(\%)\end{array}$ & SD & $\begin{array}{l}\text { Min } \\
(\%)\end{array}$ & $\begin{array}{l}\text { Max } \\
(\%)\end{array}$ & $\begin{array}{l}\text { Mean } \\
(\%)\end{array}$ & SD \\
\hline $\begin{array}{l}\text { Traditional } \\
\text { farmland }\end{array}$ & Potato & 5.6 & 11.4 & 8.3 & $1.49_{(\mathrm{n}=25)}$ & 5.7 & 11.8 & 7.7 & $1.27_{(\mathrm{n}=25)}$ & 8.3 & 14.1 & $11.6^{\mathrm{a}^{*}}$ & $1.74_{(\mathrm{n}=30)}$ \\
\hline Native grassland & $\begin{array}{l}\text { Native grasses and } \\
\text { herbs }\end{array}$ & 5.4 & 9.7 & 7.3 & $1.21_{(\mathrm{n}=25)}$ & 5.4 & 9.6 & 6.8 & $0.80_{(\mathrm{n}=25)}$ & 6.8 & 13.0 & $10.3^{\mathrm{b}}$ & $1.89_{(\mathrm{n}=30)}$ \\
\hline $\begin{array}{l}\text { Pasture } \\
\text { grassland }\end{array}$ & Alfalfa & 6.1 & 11.5 & 8.4 & $1.43_{(\mathrm{n}=25)}$ & 5.6 & 7.6 & 6.4 & $0.45_{(\mathrm{n}=25)}$ & 6.0 & 9.2 & $7.5^{\mathrm{cd}}$ & $1.03_{(\mathrm{n}=30)}$ \\
\hline \multirow[t]{2}{*}{ Shrubland } & Devid peach & 4.4 & 8.3 & 6.4 & $1.11_{(\mathrm{n}=25)}$ & 5.5 & 7.4 & 6.7 & $\left.0.42_{(\mathrm{n}=25)}\right)$ & 5.9 & 9.9 & $7.8^{\mathrm{c}}$ & $1.25_{(\mathrm{n}=30)}$ \\
\hline & Peashrub & 4.5 & 9.7 & 6.7 & $1.34_{(\mathrm{n}=25)}$ & 5.0 & 6.5 & 5.4 & $0.34_{(\mathrm{n}=25)}$ & 5.7 & 8.5 & $7.0^{\mathrm{df}}$ & $0.74_{(\mathrm{n}=30)}$ \\
\hline \multirow[t]{3}{*}{ Forestland } & Chinese arborvitae & 4.7 & 13.4 & 6.3 & $1.81_{(\mathrm{n}=25)}$ & 5.0 & 7.1 & 5.7 & $0.44_{(\mathrm{n}=25)}$ & 5.8 & 8.3 & $7.5^{\mathrm{cd}}$ & $0.82_{(\mathrm{n}=30)}$ \\
\hline & Chinese red pine & 5.4 & 11.6 & 8.1 & $1.68_{(\mathrm{n}=25)}$ & 4.2 & 7.7 & 5.9 & $0.57_{(\mathrm{n}=25)}$ & 5.6 & 8.1 & $6.9^{\mathrm{def}}$ & $0.84_{(\mathrm{n}=30)}$ \\
\hline & Siberian apricot & 4.3 & 10.6 & 6.6 & $1.51_{(\mathrm{n}=25)}$ & 5.0 & 6.5 & 5.5 & $0.35_{(\mathrm{n}=25)}$ & 5.5 & 8.7 & $7.3^{\mathrm{cd}}$ & $1.10_{(\mathrm{n}=30)}$ \\
\hline$p$ Value & & & & $0.000^{* *}$ & & & & $0.000^{* * *}$ & & & & $0.000^{* *}$ & \\
\hline
\end{tabular}

* Means with the same letter in the same column are not significantly different at the 0.05 level (LSD test, 0.05).

* Significant at $p<0.05$; Note: the alfalfa, devid peach, peashrub, Chinese arborvitae, Chinese red pine, and Siberian apricot belong to introduced vegetation.

(a)

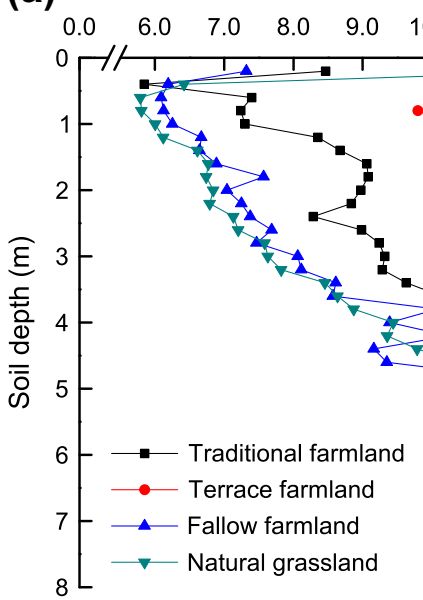

(b)

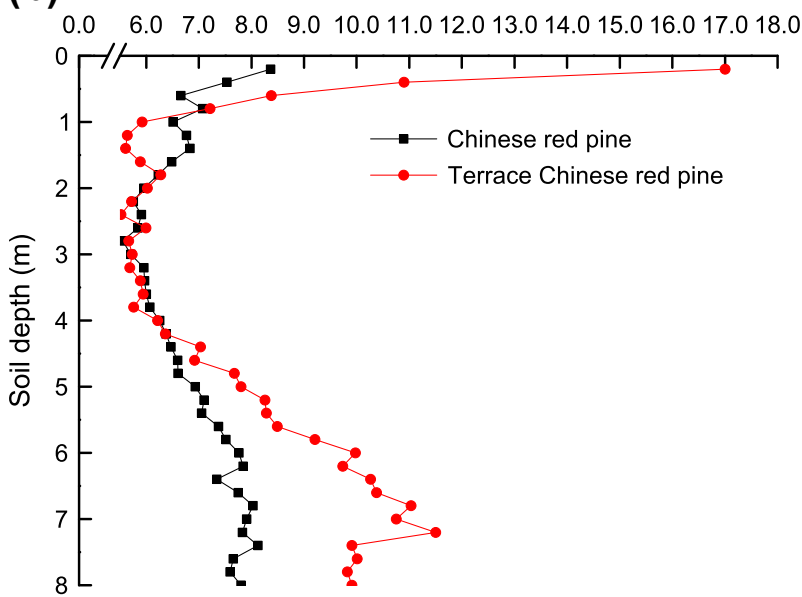

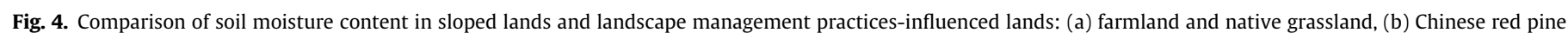

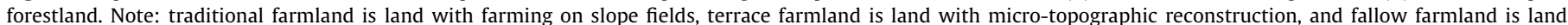

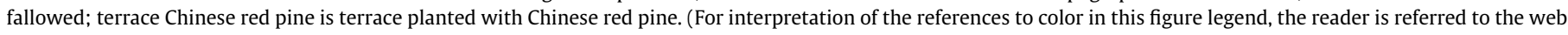
version of this article.) 
Table 4

Comparison of soil moisture in lands with different landscape management measures.

\begin{tabular}{|c|c|c|c|c|c|c|c|c|c|c|c|c|}
\hline \multirow[t]{2}{*}{ Vegetation covers } & \multicolumn{4}{|l|}{$0-1 \mathrm{~m}$} & \multicolumn{4}{|l|}{$1-2 \mathrm{~m}$} & \multicolumn{4}{|l|}{$2-8 \mathrm{~m}$} \\
\hline & $\operatorname{Min}(\%)$ & $\operatorname{Max}(\%)$ & Mean (\%) & SD & $\operatorname{Min}(\%)$ & $\operatorname{Max}(\%)$ & Mean (\%) & SD & $\operatorname{Min}(\%)$ & $\operatorname{Max}(\%)$ & Mean (\%) & SD \\
\hline Traditional farmland & 5.8 & 8.5 & 7.3 & $0.41_{(\mathrm{n}=5)}$ & 8.4 & 9.1 & 8.8 & $0.31_{(\mathrm{n}=5)}$ & 8.3 & 14.1 & $11.6^{\mathrm{a}^{*}}$ & $1.74_{(\mathrm{n}=30)}$ \\
\hline Terrace farmland & 9.8 & 11.1 & 10.4 & $0.48_{(\mathrm{n}=5)}$ & 10.1 & 10.7 & 10.4 & $0.24_{(\mathrm{n}=5)}$ & 10.5 & 15.0 & $12.1^{\mathrm{a}}$ & $1.32_{(\mathrm{n}=30)}$ \\
\hline Fallow farmland & 6.1 & 7.3 & 6.4 & $0.52_{(\mathrm{n}=5)}$ & 6.6 & 7.6 & 7.0 & $0.35_{(\mathrm{n}=5)}$ & 7.3 & 14.2 & $10.7^{\mathrm{b}}$ & $2.15_{(\mathrm{n}=30)}$ \\
\hline $\begin{array}{l}\text { Native grassland } \\
p \text { Value }\end{array}$ & 5.8 & 12.1 & $\begin{array}{l}7.2 \\
0.003^{* *}\end{array}$ & $2.76_{(\mathrm{n}=5)}$ & 6.1 & 6.8 & $\begin{array}{l}6.6 \\
0.000^{* *}\end{array}$ & $0.29_{(\mathrm{n}=5)}$ & 6.8 & 13.0 & $\begin{array}{l}10.3^{\mathrm{b}} \\
0.000^{* *}\end{array}$ & $1.89_{(\mathrm{n}=30)}$ \\
\hline Chinese red pine & 6.5 & 8.4 & 7.2 & $0.74_{(\mathrm{n}=5)}$ & 6.0 & 6.8 & 6.5 & $0.36_{(\mathrm{n}=5)}$ & 5.6 & 8.1 & $6.9^{\mathrm{a}}$ & $0.84_{(\mathrm{n}=30)}$ \\
\hline $\begin{array}{l}\text { Terrace Chinese red pine } \\
p \text { Value }\end{array}$ & 5.9 & 17.0 & $\begin{array}{l}9.9 \\
0.218\end{array}$ & $4.38_{(\mathrm{n}=5)}$ & 5.6 & 6.3 & $\begin{array}{l}5.9 \\
0.025^{* *}\end{array}$ & $0.27_{(\mathrm{n}=5)}$ & 5.5 & 11.5 & $\begin{array}{l}8.1^{b} \\
0.005^{* *}\end{array}$ & $2.00_{(\mathrm{n}=30)}$ \\
\hline
\end{tabular}

* Means with the same letter in the same column are not significantly different at the 0.05 level (LSD test, 0.05).

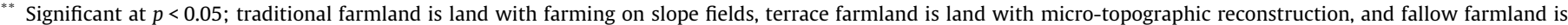
land fallowed; terrace Chinese red pine is terrace planted with Chinese red pine.

Comparisons of the five land use types below the depth of $1 \mathrm{~m}$ showed that traditional farmland had the highest soil moisture content, followed by native grassland, and forestland had the lowest value (Table 2, Fig. 2). This is consistent with previous research in the Loess Plateau (Wang et al., 2009b, 2010a, 2011b). However, the statistical analysis showed no significant difference between the three converted land use types in the deep layers (Table 2), indicating that pasture grassland, shrubland, and forestland may decrease the deep soil moisture to the same degree in this area. Furthermore, no differences in soil moisture in deep soil layers appeared between different introduced vegetations (Table 3). Previous studies found that the deep soil moisture differed significantly between traditional farmland or native grassland solely and introduced vegetation (Liu et al., 2010; Wang et al., 2011b, 2009c). In this study, although the soil moisture in deep layers varied with different introduced vegetation covers, the difference was not statistically significant among the six vegetation types that were introduced.

If the soil moisture content in native grassland was the reference value representing no human impact, then the difference in soil moisture between native grassland and lands with introduced vegetation would reflect the degree of the soil moisture deficit caused by land use change and afforestation. Although the soil moisture content in native grassland was low in this study area due to drought, the soil moisture content in converted lands with introduced vegetation was even lower (Table 3, Fig. 3). Moreover, a larger difference between land with native grass and introduced vegetation was observed with increasing soil depth. The degree of soil moisture deficit (in terms of the decreased percentage) when compared with natural soil moisture conditions, varied by vegetation type.

\subsection{Effects of landscape management on soil moisture}

Landscape management, such as micro-topography reconstruction, can effectively increase rain-water infiltration (Previati et al., 2010; Rejani and Yadukumar, 2010). This is especially true in the semi-arid Loess Plateau. For example, terrace farmland, which is typically used in landscape management in this region, can effectively intercept runoff and aid in storing rain water in the shallow soil layers (Jing and Shen, 2002). In this study, the soil moisture content in terrace farmland was higher than that in traditional farmland, especially in shallow layers (Fig. 4a). Though not statistically significant, the effect of increasing soil moisture content in the terrace farmland can be observed as far as to the depth of $4.1 \mathrm{~m}$. Soil moisture in terrace Chinese red pine was higher than that on the sloped land in the $0-1 \mathrm{~m}$ soil layers (Fig. $4 \mathrm{~b}$ ). The Chinese red pine in the Loess Plateau usually has strong root systems with high soil moisture consumption ability. In the $2-4.2 \mathrm{~m}$ soil layers, the mean soil moisture of Chinese red pine planted on sloped land and terraced land was 5.94\% and 5.86\%, respectively, with no significant difference between the two land types in this layer. Previous researchers pointed out that micro-topography reconstruction measures only effect soil moisture in shallow layers, but not in deep layers ( $\mathrm{Li}, 1983$ ). Others have reported that rainfall water cannot infiltrate the dry soil layers in introduced vegetation (Chen et al., 2008a). However, in this study, the soil moisture of the terrace Chinese red pine in layers below $2.0 \mathrm{~m}$ was significant higher than that on the sloped land (Table 4). This finding suggests that the micro-topography affected soil moisture not only in shallow layers, but also in deep soil layers.

Tillage activities have a considerable influence on soil moisture. In farmland, tillage activities usually break down the normal structure and loosen the structure of topsoil, decreasing soil bulk density (Jin et al., 2007), which in turn increases the rain-water infiltration capacity and increases soil moisture in shallow layers (Wang et al., 2009a). In this study, as shown in Table 2 and Fig. 2a, pasture grassland had relatively higher mean soil moisture content than other introduced vegetation types, especially in 2010. This was because the alfalfa field was cultivated by farmers. The cultivation practices loosen the upper soil structure, increasing the soil moisture content in shallow soil layers. However, high soil moisture consumption due to the deep root systems of alfalfa resulted in low soil moisture content in deep layers.

As a landscape management practice, fallow farmland may also influence soil moisture. Qiu et al. (2001) found that soil moisture decreases in the $0-0.75$ m layer when converting farmland to fallow land. Interestingly, in our study, the soil moisture in the fallow farmland decreased in the overall $0-8 \mathrm{~m}$ soil profile when compared with traditional farmland, and the value was close to native grassland after 7 years of fallow practices (Fig. 4a). This result suggests that a lack of cultivation may lead to a decrease in soil moisture not only in shallow soil layers, but also in deep layers.

\subsection{Soil hydrological viability to large-scale afforestation}

In the Loess Plateau, the introduced vegetation with high planting density and productivity usually leads to greater consumption of soil moisture and disturbs the balance of soil moisture and vegetation, leading to soil moisture deficit in deep layers (Yang, 1996). Li et al. (2008) simulated the water yield changes among different planting densities of black locust (Robinia pseudoacacia) in the Loess Plateau using the WinEPIC model. Their results showed that higher planting density was associated with a greater decrease in deep soil moisture. Wang (2007) further showed that cutting shrubs and trees to low density can improve soil moisture 
conditions in deep soil layers. The planting density of the shrub land in our study was near 2222 plants/ha, and the planting density of the forestland was near 1,900 plants/ha (Table 1). The appropriate planting density in this study area should be less than 833 plants/ha (Jin et al., 2011). The actual planting density was far higher than the recommended value. Thus, it is not surprising to see decreased soil moisture content in the soil layers, especially in the deep soil layers. The high planting density is considered to be the main cause of the soil moisture deficit.

To maintain sustainable vegetation restoration in the arid and semi-arid regions, the soil moisture conditions should be evaluated before afforestation (Normile, 2007; Yang and Tian, 2004). Furthermore, to prevent soil moisture deficit, the natural vegetation succession should be followed. For example, Chen et al. (2008a) and Cao et al. (2011) proposed that regions with annual rainfall less than $400 \mathrm{~mm}$ are unsuitable for large-scale afforestation. Hou and Han (2000) suggested that native dominant species are naturally selected by the environment and should have good adaptability for local environment. However, the field investigation of our study revealed that the native dominant species, such as tree of heaven (Ailanthus altissima), grew only sporadically in the catchment. Based on the comparison of soil moisture in lands with different introduced vegetation types, afforestation would lead to soil moisture deficit, as observed in our study. This indicates that largescale afforestation with high planting density is not suitable for this area regardless of the type of vegetation introduced (e.g., alfalfa, canagana peashrub, Chinese red pine, Chinese arborvitaes and Siberian apricot).

Because vegetation restoration and afforestation have been conducted for years, large-scale deep soil moisture deficit is appearing in the Loess Plateau and other semi-arid areas in the world (Chen et al., 2008a; Sizemskaya et al., 2009). Furthermore, due to the reliance on afforestation in the vegetation restoration of arid and semi-arid regions (Cao et al., 2011), the soil moisture conditions should be a critical issue for vegetation restoration in these areas. The soil moisture in deep soil layers needs to be restored in order to sustain the introduced vegetation. The deep soil moisture is difficult to replenish in areas with low annual rainfall (Chen et al., 2008a). In this study, the results show that landscape management practices can effectively increase soil moisture in both shallow and deep soil layers. For the sustainability of large-scale vegetation restoration and afforestation in the semi-arid loess plateau and other similar regions in the world, controlling the planting density and following appropriate landscape management should be considered.

\section{Conclusion}

In this study, changes in soil moisture content were assessed by comparing different vegetation types investigated in a typical semi-arid loess hilly catchment in the Loess Plateau of China. The results indicated that available soil moisture decreased more than $35 \%$ when converted to pasture grassland, shrubland, and forestland as compared with traditional farmland. No significant effects on deep soil moisture were found between the converted land use types. Soil moisture deficits occurred in lands with introduced vegetations, but no significant differences were found among the different introduced vegetation types. Introduced vegetation types in the semi-arid area may have similar soil hydrological effects. The high planting density of the introduced vegetation may be the key factor in soil moisture deficit. Landscape management activities such as tillage, micro-topography reconstruction, and farmland fallow can affect soil moisture in both shallow and deep soil layers. Tillage management and micro-topography reconstruction can be used as effective countermeasures to reduce the soil moisture def- icit. For sustainable vegetation restoration in semi-arid regions, the density of planted vegetation should be scientifically evaluated and determined according to local soil moisture viability and specific plant species.

\section{Acknowledgements}

This study was supported by the National Natural Science Foundation of China (40925003, 40801041). We thank the editor and anonymous reviewers for their constructive comments and suggestions.

\section{References}

Arnell, N.W., 1999. Climate change and global water resources. Global Environ. Change 9 (1), 31-49.

Cao, S.X., Chen, L., Shankman, D., Wang, C.M., Wang, X.B., Zhang, H., 2011. Excessive reliance on afforestation in China's arid and semi-arid regions: lessons in ecological restoration. Earth Sci. Rev. 104, 240-245.

Chazdon, R.L., 2008. Beyond deforestation: restoring forests and ecosystem services on degraded lands. Science 320, 1458-1460.

Chen, H.S., Shao, M.A., Li, Y.Y., 2008a. Soil desiccation in the Loess Plateau of China. Geoderma 143, 91-100

Chen, H.S., Shao, M.A., Li, Y.Y., 2008b. The characteristics of soil water cycle and water balance on steep grassland under natural and simulated rainfall conditions in the Loess Plateau of China. J. Hydrol. 360, 242-251.

Chen, L.D., Huang, Z.L., Gong, J., Fu, B.J., Huang, Y.L., 2007a. The effect of land cover/ vegetation on soil water dynamic in the hilly area of the Loess Plateau, China. Catena 70, 200-208.

Chen, L.D., Wei, W., Fu, B.J., Lü, Y.H., 2007b. Soil and water conservation on the loess plateau in China: review and perspective. Prog. Phys. Geogr. 31 (4), 389-403.

Chen, L.D., Wang, J.P., Wei, W., Fu, B.J., Wu, D.P., 2010. Effects of landscape restoration on soil water storage and water use in the Loess Plateau Region, China. For. Ecol. Manage. 259, 1291-1298.

Cong, X.H., Liang, Y.M., Li, D.Q., 1990. Root characteristics of Hippophae rhamnoides and dynamic of soil water in semi-arid of Loess Plateau. Bull. Soil Water Conserv. 10 (6), 98-103 (in Chinese).

Dobriyal, P., Qureshi, A., Badola, R., Hussain, S.A., 2012. A review of the methods available for estimating soil moisture and its implications for water resource management. J. Hydrol. 458-459, 110-117.

February, E.C., Higgins, S.I., 2010. The distribution of tree and grass roots in savannas in relation to soil nitrogen and water. S. Afr. J. Bot. 76 (3), 517-523.

Gates, J.B., Scanlon, B.R., Mu, X., Zhang, L., 2011. Impacts of soil conservation on groundwater recharge in the semi-arid Loess Plateau, China. Hydrogeol. J. 19, 865-875.

Hou, Q.C., Han, R.L., 2000. Problems on vegetation construction in Loess Plateau region. Bull. Soil Water Conserv. 20 (2), 53-56 (in Chinese).

Huang, M.B., Shao, M.A., Zhang, L., Li, Y.S., 2003. Water use efficiency and sustainability of different long-term crop rotation systems in the Loess Plateau of China. Soil Tillage Res. 72, 95-104.

Jin, K., Cornelis, W.M., Schiettecatte, W., Lu, J.J., Yao, Y.Q., Wu, H.J., Gabriels, D., Neve, S.D., Cai, D.X., Jin, J.Y., Hartmann, R., 2007. Effects of different management practices on the soil-water balance and crop yield for improved dryland farming in the Chinese Loess Plateau. Soil Tillage Res. 96, 131-144.

Jin, T.T., Fu, B.J., Liu, G.H., Wang, Z., 2011. Hydrologic feasibility of artificial forestation in the semi-arid Loess Plateau of China. Hydrol. Earth Syst. Sci. 15, 2519-2530.

Jing, K., Shen, Y.C., 2002. Study on influence of soil and water conservation in the Loess Plateau to future water resources. Soil Water Conserv. China 1,12-14 (in Chinese).

Legates, D.R., Mahmood, R., Levia, D.F., Deliberty, T.L., Quiring, S.M., Houser, C., Nelson, F.E., 2011. Soil moisture: a central and unifying theme in physical geography. Prog. Phys. Geogr. 35 (1), 65-86.

Li, Y.S., 1983. The properties of water cycle in soil and their effect on water cycle for land in the Loess Plateau. Acta Ecol. Sini. 3 (2), 91-101 (in Chinese).

Li, J., Wang, X.C., Shao, M.A., Zhao, Y.J., Li, X.F., 2008. Simulation of water productivity and soil desiccation effects of different planting density black locust forestland on the Loess Plateau. Acta Ecol. Sini. 28 (7), 3125-3142 (in Chinese).

Liu, J.G., Li, S.X., Ouyang, Z.Y., Tam, C., Chen, X.D., 2008a. Ecological and socioeconomic effects of China's policies for ecosystem services. Proc. Natl. Acad. Sci. USA 105 (28), 9477-9482.

Liu, Q., Yang, Z.F., Cui, B.S., 2008b. Spatial and temporal variability of annual precipitation during 1961-2006 in Yellow River Basin, China. J. Hydrol. 361, 330-338.

Liu, W.Z., Zhang, X.C., Dang, T.H., Ouyang, Z., Li, Z., Wang, J., Wang, R., Gao, C.Q., 2010. Soil water dynamics and deep soil recharge in a record wet year in the southern Loess Plateau of China. Agric. Water Manage. 97 (8), 1133-1138.

McVicar, T., Niel, T., Li, L.T., Wen, Z.M., Yang, Q.K., Li, R., Jiao, F., 2010. Parsimoniously modeling perennial vegetation suitability and identifying priority areas to support China's re-vegetation program in the Loess Plateau: matching model complexity to data availability. For. Ecol. Manage. 259, 1277-1290. 
Meerveld, H.J.T., Mcdonnell, J.J., 2006. On the interrelations between topography, soil depth, soil moisture, transpiration rates and species distribution at the hillslope scale. Adv. Water Resour. 29, 293-310.

Mishra, A.K., Singh, V.P., 2010. A review of drought concepts. J. Hydrol. 391, 202216.

Mu, X.M., Xu, X.X., Wang, W.L., Wen, Z.M., Du, F., 2003. Impact of artificial forest on soil moisture of the deep soil layer on Loess Plateau. Acta Pedol. Sin. 40 (2), 210217 (in Chinese).

Normile, D., 2007. Getting at the roots of killer dust storms. Science 317, 314-316.

Oki, T., Kanae, S., 2006. Global hydrological cycles and world water resources. Science 313, 1068-1072.

Piao, S.L., Ciais, P., Huang, Y., Shen, Z.H., Peng, S.S., Li, J.S., Zhou, L.P., Liu, H.Y., Ma, Y.C., Ding, Y.H., Friedlingstein, P., Liu, C., Tan, K., Yu, Y.Q., Zhang, T.Y., Fang, J.Y., 2010. The impacts of climate change on water resources and agriculture in China. Nature 467, 43-51.

Porporato, A., D’Odorico, P., Laio, F., Ridolfi, L., Rodriguez-Iturbe, I., 2002. Ecohydrology of water-controlled ecosystems. Adv. Water Resour. 25, 13351348.

Previati, M., Bevilacqua, I., Canone, D., Ferraris, S., Haverkamp, R., 2010. Evaluation of soil water storage efficiency for rainfall harvesting on hillslope micro-basins built using time domain reflectometry measurements. Agric. Water Manage. 97, 449-456.

Pu, J.Y., Yao, X.Y., Den, Z.Y., Zhang, C.J., Zhang, M.C., Wang, W.T., 2006. Impact of climate change on soil water content in Loess Plateau, Gansu. Chin. J. Soil Sci. 37 (6), 1086-1090 (in Chinese).

Qiu, Y., Fu, B.J., Wang, J., Chen, L.D., 2001. Spatial variability of soil moisture content and its relation to environmental indices in a semi-arid gully catchment of the Loess Plateau, China. J. Arid Environ. 49, 723-750.

Rejani, R., Yadukumar, N., 2010. Soil and water conservation techniques in cashew grown along steep hill slopes. Sci. Hortic. 126, 371-378.

Scanlon, B.R., Keese, K.E., Flint, A.L., Flint, L.E., Gaye, C.B., Edmunds, W.M., Simmers, I., 2006. Global synthesis of groundwater recharge in semiarid and arid regions. Hydrol. Process. 20, 3335-3370.

Seneviratne, S.I., Corti, T., Davin, E.L., Hirschi, M., Jaeger, E.B., Lehner, I., Orlowsky, B., Teuling, A.J., 2010. Investigating soil moisture-climate interactions in a changing climate: a review. Earth Sci. Rev. 99, 125-161.

Shi, Z.H., Chen, L.D., Hao, J.P., Wang, T.W., Cai, C.F., 2009. The effects of land use change on environmental quality in the red soil hilly region, China: a case study in Xianning County. Environ. Monit. Assess. 150 (1), 295-306.

Sizemskaya, M.L., Jiao, J.Y., Wang, N., Sapanov, M.K., Wu, Q.X., Jia, Y.F., Kolesnikov, A.V., Liu, G.B., Sapanov, P.M., 2009. Specificity of afforestation under conditions of moisture deficit in south of Russian plain and the Loess Plateau of China. Res. Soil Water Conserv. 16 (5), 73-77 (in Chinese).

Sun, G., Zhou, G., Zhang, Z., Wei, X., McNulty, S.G., James, M.V., 2006. Potential water yield reduction due to forestation across China. J. Hydrol. 328, 548-558.

Vörösmarty, C.J., Green, P., Salisbury, J., Lammers, R.B., 2000. Global water resources: vulnerability from climate change and population growth. Science 289, 284-288.
Wang, H.S., 2007. Discussion on feedback effect of soil desiccation by vegetation and related issues. Progress Geography 26 (6), 33-39 (in Chinese).

Wang, X.L., Sun, G.J., Jia, Y., Li, F.M., Xu, J.Z., 2008. Crop yield and soil water restoration on 9-year-old alfalfa pasture in the semiarid Loess Plateau of China. Agric. Water Manage. 95, 190-198.

Wang, Q.K., Chen, H., Li, H.W., Li, W.Y., Wang, X.Y., McHugh, A.F., He, J., Gao, H.W. 2009a. Controlled traffic farming with no tillage for improved fallow water storage and crop yield on the Chinese Loess Plateau. Soil Tillage Res. 104, 192 197.

Wang, Z.Q., Liu, B.Y., Zhang, Y., 2009b. Soil moisture of different vegetation types on the Loess Plateau. J. Geog. Sci. 19 (6), 707-718.

Wang, Z.Q., Liu, B.Y., Liu, G., Zhang, Y.X., 2009c. Soil water depletion depth by planted vegetation on the Loess Plateau. Sci. China Ser. D - Earth Sci. 52 (6) 835-842.

Wang, Y.Q., Shao, M.A., Liu, Z.P., 2010a. Large-scale spatial variability of dried soil layers and related factors across the entire Loess Plateau of China. Geoderma 159, 99-108.

Wang, Y.Q., Shao, M.A., Shao, H.B., 2010b. A preliminary investigation of the dynamic characteristics of dried soil layers on the Loess Plateau of China. J. Hydrol. 381, 9-17.

Wang, L., Wei, S.P., Horton, R., Shao, M.A., 2011a. Effects of vegetation and slope aspect on water budge in the hill and gully region of the Loess Plateau of China. Catena 87, 90-100.

Wang, Y.Q., Shao, M.A., Zhu, Y.J., Liu, Z.P., 2011b. Impacts of land use and plant characteristics on dried soil layers in different climatic regions on the Loess Plateau of China. Agric. For. Meteorol. 151, 437-448.

Wei, W., Chen, L.D., Fu, B.J., Chen, J., 2010. Water erosion response to rainfall and land use in different drought-level years in a loess hilly area of China. Catena 81 (1), 24-31.

Xie, X.Q., Wang, L., 2007. Changes of potential evaporation in Northern China over the past 50 years. J. Nat. Resour. 22 (5), 683-691 (in Chinese).

Yang, W.X., 1996. The preliminary discussion on soil desiccation of artificial vegetation in the northern regions of China. Sci. Silvae Sini. 32 (1), 78-85 (in Chinese).

Yang, W.Z., Tian, J.L., 2004. Essential exploration of soil aridization in Loess Plateau. Acta Pedol. Sin. 41 (1), 1-6 (in Chinese).

Yang, X.H., Jia, Z.Q., Ci, L.J., 2010. Assessing effects of afforestation projects in China. Nature $315,466$.

Yang, L., Wei, W., Chen, L., Jia, F., Mo, B., 2012. Spatial variations of shallow and deep soil moisture in the semi-arid Loess Plateau, China. Hydrol. Earth Syst. Sci. 16, 3199-3217.

Yang, L., Wei, W., Mo, B.R., Chen, L.D., 2011. Soil water deficit under different artificial vegetation restoration in the semi-arid hilly region of the Loess Plateau. Acta Ecol. Sini. 31 (11), 3192-3200 (In Chinese).

Yao, Y.B., Wang, Y.R., Li, Y.H., Zhang, X.Y., 2005. Climate warming and drying and its environmental effects in the Loess Plateau. Resour. Sci. 27 (5), 146-152 (in Chinese). 